5. Siegel M, Goldberg M: Incidence of poliomyelitis in pregnancy. N Engl J Med 253:841-847, 1955

6. Hodes $\mathrm{H}$ : Effect of pregnancy upon the immunity of mice vaccinated against St. Louis encephalitis virus. J Exp Med 69:533-543, 1939

7. Amstey MS: Effect of pregnancy hormones on herpesvirus and other DNA viruses. Am J Obstet Gynecol 129:159-163, 1977

8. Menegus MA, Douglas RG: Viruses, ricketssiae, chlamydia and mycoplasmas, in Mandell GL, Douglas RG, Bennett JE (eds): Principles and Practice of Infectious Diseases. New York, John Wiley \& Sons, 1979, pp 175-191

9. Whitely RJ, Alford CA Jr: Towards therapy and prevention of herpetic infections. Semin Perinatol 7:64-81, 1983

10. Wishnow RH, Steinfeld JL: The conquest of the major infectious diseases in the United States: A bicentennial retrospective. Annu Rev Microbiol 30:427-450, 1976

\title{
77. GENERAL CONSIDERATIONS OF VIRAL RESPIRATORY DISEASES
}

\author{
Sandra Nusinoff Lehrman
}

\section{DEFINITION}

Viral respiratory illnesses are ubiquitous in the general population. Syndromes of mild-to-moderate illness characterized by generalized malaise, fatigue, coryza, and cough are usually endemic in the community during the winter months. These nonspecific upper respiratory infections are commonly seen in preschool and grammarschool children and are often brought home by these children to their pregnant mothers. Many viral respiratory illnesses are clinically trivial and are not responsible for any significant morbidity. Pregnant women, however, often report the occurrence of a viral respiratory illness during their gestation and are concerned about its potential impact on their pregnancy and on the fetus they are carrying.

\section{ETIOLOGY}

Viral respiratory illness can be caused by a large number of viruses belonging to several different taxonomic groups. Although some of these viruses cause characteristic syndromes that allow presumptive diagnosis on clinical grounds, the overlap of clinical symptoms is great. The groups of viruses most commonly associated with acute viral respiratory disease are indicated in Table 77-1. They include influenza, adenoviruses, parainfluenza viruses, respiratory syncytial virus, the rhinovirus group of picornaviruses, and coronaviruses. ${ }^{1}$ Respiratory illnesses are less commonly associated with enterovirus infection. In immunocompromised patients, DNA viruses such as herpes simplex virus, varicellazoster virus, and cytomegalovirus may cause pneumonia. Pregnant women at term may be at increased risk for varicella pneumonia.

\section{PATHOGENESIS AND PATHOLOGY}

Acute viral respiratory infections are generally limited in the pathophysiological changes they produce. The initial site of virus replication is in the nasopharyngeal mucosa, which is infected when the patient inhales droplet nuclei created by the sneezing and coughing of other affected individuals. The viruses multiply locally, and there is little further dissemination of virus either contiguously to the lower respiratory tract or systemically through viremia. The most common viral respiratory illnesses, because they are not associated with a viremic phase, are not associated with any direct fetal infection. Therefore, one might expect the incidence of fetal wastage and congenital malformations to be small. As a group, these viruses have not been associated with any increased incidence of fetal complications of pregnancy with the possible exception of influenza during major epidemics. ${ }^{2-5}$ Influenza is discussed in greater detail in Chapter 79.

Acute viral respiratory illnesses, although generally trivial, may be responsible for some respiratory embarrassment in pregnant women late in their gestations. Although the degree of respiratory compromise secondary to these viruses may be small, it may compound the normal physiological mechanical limitation of maternal ventilation by the fetus. Women at term have decreased functional residual capacities despite the fact that minute ventilation may be maintained or, in fact, increased.6,7 Compromise of their pulmonary function, however slight, by direct viral infection of the respiratory mucosa and/or increased demands for ventilation in response to an acute illness may cause pregnant women more respiratory distress than otherwise healthy nonpregnant females.

Women suffering from viral respiratory infections during pregnancy may take a variety of medications for relief of symptoms of their illness, with or without a physician's recommendation. The safety of most drug use in pregnancy has not been adequately evaluated. Respiratory infections may affect maternal and fetal outcome indirectly through side effects of concurrent drug use. For instance, the increased incidence of central nervous system malformations associated with 1957-1958 influenza 
TABLE 77-1. Physical Characterization of Viruses Associated with Respiratory Illnesses

\begin{tabular}{|c|c|c|c|c|c|c|}
\hline Virus & $\begin{array}{l}\text { Nucleic } \\
\text { acid }\end{array}$ & Envelope & $\begin{array}{l}\text { Ether } \\
\text { sensitive }\end{array}$ & $\begin{array}{l}\text { Diameter } \\
\text { of virion } \\
\quad(\mathrm{nm})\end{array}$ & $\begin{array}{l}\text { Virus } \\
\text { subgroups }\end{array}$ & $\begin{array}{l}\text { Number of } \\
\text { serotypes }\end{array}$ \\
\hline Orthomyxovirus & RNA & + & + & $80-120$ & Influenza & $\begin{array}{l}\text { 3: Types } A, B \text {, and } C \text {, } \\
\text { major strain } \\
\text { variations common }\end{array}$ \\
\hline $\begin{array}{l}\text { Paramyxovirus } \\
\text { pneumovirus }\end{array}$ & RNA & + & + & 130 & $\begin{array}{l}\text { Respiratory } \\
\text { syncytial } \\
\text { virus }\end{array}$ & Single \\
\hline Paramyxovirus & RNA & + & + & 150 & $\begin{array}{l}\text { Parainfluenza } \\
\text { virus }\end{array}$ & 4: Types 1-4 \\
\hline Picornavirus & RNA & - & - & $25-30$ & $\begin{array}{l}\text { Rhinovirus } \\
\text { Enterovirus } \\
\text { Coxsackie A } \\
\text { Coxsackie B } \\
\text { Echovirus } \\
\text { Poliovirus } \\
\text { Hepatitis A } \\
\text { Enteroviruses }\end{array}$ & $\begin{array}{r}>100 \\
>70 \\
24 \\
6 \\
>34 \\
3 \\
1 \\
2\end{array}$ \\
\hline Coronavirus & RNA & + & + & $70-120$ & Coronavirus & 4 \\
\hline Adenovirus & DNA & - & - & 75 & $\begin{array}{l}\text { Groups A through } E \\
\text { based on ability to } \\
\text { transform cells and } \\
\text { clinical syndromes }\end{array}$ & 39 \\
\hline Herpes & DNA & + & + & 200 & $\begin{array}{l}\text { Herpes simplex } \\
\text { Varicella-zoster } \\
\text { Cytomegalovirus } \\
\text { Epstein-Barr virus }\end{array}$ & $\begin{array}{l}2 \\
1 \\
1 \\
1\end{array}$ \\
\hline
\end{tabular}

in Scandinavia is also directly related to use of antipyretic drugs.

\section{EPIDEMIOLOGY}

Clinical illness associated with respiratory virus infections is most commonly seen during the late fall and early winter. It is difficult to differentiate the illness caused by on'e group of viruses, for instance, parainfluenza viruses, from that of another group such as the respiratory syncytial virus on the basis of seasonal prevalence. However, as a general rule, the parainfluenza viruses are most often isolated in the late fall and early winter, whereas respiratory syncytial viruses are seen in the winter and early spring most commonly. Rhinoviruses may be isolated year round and tend to be distributed evenly through the winter months. Because of the large number of serotypes of rhinoviruses and incomplete immunity induced by parainfluenza virus infection, there is a constant pool of young children at risk for disease from these agents, and epidemics occur each winter. Respiratory syncytial virus epidemics classically occur at 2-year intervals. The epidemiology of influenza virus infection is more complicated and is discussed in Chapter 79. As a general rule, illness caused by all of these viruses is more common in the winter because of their transmission by droplet nuclei and the facilitation of this mode of spread of disease in the winter months when people are indoors and placed in situations in which population density is greater. Rhinovirus disease is most efficiently spread by inoculation of mucosal surfaces of the nose and eyes by hand or fomites contaminated by secretions of an infected individual. Significant hand and fomite transmission of virus also is found in respiratory syncytial virus disease.

\section{MANIFESTATIONS}

The clinical syndromes associated with the common human respiratory viruses are summarized in Table 77-2. Many of these illnesses are referred to in one form or another as the common cold. This is an illness characterized by nasal congestion, coryza, mild pharyngitis, malaise, and occasional mild headache. There is usually mild to minimal fever associated with the disease. Acute respiratory illness caused by adenoviruses and influenza may be more severe, and constitutional symptoms and fever are often reported.

\section{DIAGNOSIS}

Acute viral respiratory illnesses are generally diagnosed on the basis of the clinical syndromes described above. A specific viral etiology is difficult to determine from signs and symptoms alone. The fever, malaise, and myalgia associated with influenza may allow one to differentiate disease caused by this virus from the less severe rhinovirus, parainfluenza, and respiratory syncytial virus diseases. The occurrence of conjunctivitis and several other specific syndromes in association with ade- 
TABLE 77-2. Clinical Syndromes Associated with Respiratory Viruses in Older Children and Adults ${ }^{a}$

\begin{tabular}{|c|c|c|c|c|c|c|}
\hline Agent & Rhinitis & Pharyngitis & $\begin{array}{c}\text { Lower airway } \\
\text { disease }\end{array}$ & Pneumonia & Constitutional & Fever \\
\hline Rhinoviruses & ++ & \pm & + & Rare & \pm & $\begin{array}{l}\text { Usually } \\
\text { afebrile }\end{array}$ \\
\hline Influenza $\mathrm{A}, \mathrm{B}$ & + & + & ++ & $\begin{array}{l}\text { Severe when } \\
\text { present }\end{array}$ & ++ & High \\
\hline $\begin{array}{l}\text { Parainfluenza } \\
\text { viruses }\end{array}$ & + & ++ & $++b$ & Rare & + & $\begin{array}{l}\text { Low or no } \\
\text { fever }\end{array}$ \\
\hline $\begin{array}{l}\text { Respiratory } \\
\text { syncytial virus }\end{array}$ & ++ & + & $+c$ & $?$ & + & $\begin{array}{l}\text { Usually } \\
\text { afebrile }\end{array}$ \\
\hline Adenoviruses & + & ++ & ++ & $\begin{array}{l}\text { Severe when } \\
\text { present }\end{array}$ & ++ & High \\
\hline $\begin{array}{c}\text { Coxsackie and } \\
\text { echoviruses }\end{array}$ & \pm & + & + & $?$ & ++ & $\begin{array}{r}\text { Moderate } \\
\text { to high }\end{array}$ \\
\hline Coronaviruses & $++^{d}$ & + & \pm & $?$ & \pm & Mild \\
\hline
\end{tabular}

${ }^{a}++$, severe; + , moderately severe; \pm , mild; ?, unknown or uncommon.

${ }^{b}$ Laryngeal involvement common.

'Especially in older patients.

${ }^{d}$ Varies with serotype from none to severe.

noviral infection may also aid differential diagnosis on clinical grounds.

Identification of the specific etiology of acute viral respiratory illness depends on the demonstration of viral antigens in nasal secretions or stool, the isolation of the virus in tissue culture, or the documentation of rising titers of specific antibody to that virus. Isolation in tissue culture remains the benchmark for determining the etiology of a viral disease; however, several more rapid methods allowing presumptive diagnosis of viral infection can be used. Virus-coded antigens of influenza virus, parainfluenza viruses, and respiratory syncytial virus can be demonstrated in fixed smears of nasal epithelial cells with commercially available fluorescein-conjugated specific antibodies. Several methods of determining immune status and documenting seroconversion have been developed for respiratory viruses. Complement-fixation tests are relatively insensitive, but assays for virus-specific antibody using the newer techniques of enzyme-linked immunosorbant assay (ELISA) and radioimmunoassay (RIA) are excellent tests and are available both commercially and through State Health Departments.

\section{TREATMENT}

Treatment of acute viral respiratory illness is generally supportive. It is important especially in pregnant women to maintain adequate hydration and control excessive fever if present. Because of their unknown risk for the fetus, medications for symptomatic relief such as antihistamines and decongestants are probably contraindicated. Several specific antiviral agents effective against respiratory viruses are currently licensed or in the developmental stages. Amantadine and rimantadine are effective for prophylaxis against influenza infection and also may decrease the severity of established illness. Ribavirin, another antiviral agent, has been shown in small clinical trials to modify the course of severe respiratory syncytial virus disease and parainfluenza virus dis- ease in young infants. The risks of use of these agents in pregnant women are not well defined. Ribavirin is teratogenic in rabbits and rats and should not be used. 8

\section{PREVENTION}

Other than influenza immunization, there are no specific preventative measures for acute viral respiratory illness. Several common-sense public health measures may decrease the risk of acquiring acute respiratory disease. When outbreaks of acute respiratory illness are present in the community, one might avoid infection by avoiding crowded places, particularly where there are concentrations of small children. In hospital settings and in the home, good hand washing appears to be the best method to decrease the spread of acute respiratory illness.

\section{REFERENCES}

1. Knight V: General considerations of viral respiratory disease, in Knight V (ed): Viral and Mycoplasmal Infections of the Respiratory Tract. Philadelphia, Lea \& Feiburger, 1973

2. Grossman JH III: Perinatal viral infections. Clin Perinatol 7:257-271, 1980

3. Grossman JH III: Viral infections in obstetrics and gynecology. Obstet Gynecol Annu 9:55-76, 1980

4. Sever JL: Infectious Agents as Teratogens. Methods for Detection of Environmental Agents That Produce Congenital Defects. Amsterdam, North-Holland, 1975, pp 221-232

5. Tobin $\mathrm{O}^{\prime} \mathrm{HJ}$, Marshall WC, Peckham CS: Virus infections. Clin Obstet Gynecol 4:479-501, 1977

6. Leontic EA: Respiratory disease in pregnancy. Med Clin North Am 61:111-128, 1977

7. Schoenbaum SC, Weinstein L: Respiratory infection in pregnancy. Clin Obstet Gynecol 22:293-300, 1979

8. Hall CB, McBride JT, Walsh EE, et al: Aerosolized ribavirin treatment of infants with respiratory syncytial viral infection. N Engl J Med 308:1443-1447, 1983 